\title{
NEMOKAMOS MEDICINOS PAGALBOS TEIKIMO KONSTITUCINĖS GARANTIJOS
}

\author{
Indrè Špokienė \\ Mykolo Romerio universiteto Teisès fakulteto \\ Teisès filosofijos ir istorijos katedra \\ Ateities g. 20, LT-08303 Vilnius \\ Telefonas (+370 5) 2714697 \\ Elektroninis paštas indrespokiene@gmail.com \\ Pateikta 2013 m. birželio 18 d., parengta spausdinti 2013 m. rugsèjo $18 \mathrm{~d}$. \\ doi:10.13165/SPV-13-1-5-02
}

\section{Santrauka}

Didejant sveikatos priežiūros paslaugu poreikiui ir esant ribotiems ištekliams klausimai dèl nemokamos medicinos pagalbos sampratos, teisés i tokia pagalbq subjektu, apimties bei finansavimo yra labai aktualūs ir teorine, ir praktine prasme. $2013 \mathrm{~m}$. gegužés $16 \mathrm{~d}$. Lietuvos Respublikos Konstitucinis Teismas priemė nutarima, kuriame išaiškino Konstitucijos 53 straipsnio 1 dalies normos, numatančios valstybès priedermę rüpintis žmoniu sveikata ir užtikrinti medicinos pagalba bei paslaugas žmogui susirgus, taip pat konstitucinès nemokamos medicinos pagalbos piliečiams valstybinèse gydymo ịstaigose garantijos turinị. Iš esmés čia galima rasti gaires, kaip mūsų šalyje turès būti teikiamos sveikatos priežiūros paslaugos ir kokiais būdais jos turi būti finansuojamos. Naujoji oficiali konstituciné doktrina šiuo klausimu neabejotinai turès įtakos tolesniam nemokamos medicinos pagalbos ir kitu sveikatos priežiūros paslaugu teikimo teisiniam reguliavimui, taigi ir šios teisés igyvendinimui. Todè šiame straipsnyje sistemiškai išanalizuotas ir atskleistas nemokamos medicinos pagalbos teikimo Lietuvoje konstituciniu garantiju pobüdis, dabartinis ju turinys ir ypatumai nacionalinèje teisèje bei naujojoje konstitucineje doktrinoje.

Reikšminiai žodžiai: nemokama medicinos pagalba, valstybès laiduojama medicinos pagalba, teisè i nemokamą medicinos pagalbą, sveikatos priežiūra, teisè i sveikatos priežiūrą.

\section{Ivadas}

Konstituciniai sveikatos apsaugos pagrindai yra įtvirtinti Lietuvos Respublikos Konstitucijos 53 straipsnio 1 dalyje, kurioje nustatyta: „Valstybè rūpinasi žmonių sveikata ir laiduoja medicinos pagalbą bei paslaugas žmogui susirgus. İstatymas nustato piliečiams nemokamos medicinos pagalbos valstybinèse gydymo įstaigose teikimo tvarką. ${ }^{11}$ Bemaž du dešimtmečius, nuo pat Konstitucijos prièmimo, šių iš pažiūros lakoniškų, todèl lyg ir savaime 
suprantamų normų analizei mokslininkai neskyrè daug dėmesio. Galbūt todèl, kad ir konstitucinès doktrinos šiuo klausimu praktiškai nebuvo. Tam tikrų iž̌valgų galima rasti teisininkų J. Juškevičiaus ${ }^{2}$, P. Čelkio ${ }^{3}$, T. Birmontienès ${ }^{4}$, L. Beliūnienès ${ }^{5}$, taip pat straipsnio autorès ankstesnèse publikacijose ${ }^{6}$, kur gvildenamos teisès i sveikatos priežiūrą sampratos, ịtvirtinimo ir igyvendinimo problemos. Tuo tarpu konkrečiai teisès ị nemokamą gydymą temą daugiau nei prieš aštuonerius metus yra nagrinejjęs tik L. Markauskas. Taigi tema sveikatos teisès doktrinoje pakankamai nauja, labai mažai tyrinèta. Pastarųjų metų situacija sveikatos apsaugos sektoriuje patvirtina, kad ji igyja vis didesni praktinị aktualumą: akivaizdu, kad dèl augančių sveikatos priežiūros paslaugų poreikių ir jų kokybės standartų, sudètingesnių ir brangesnių sveikatos priežiūros technologijų nuolat didejja ir šių paslaugų teikimo išlaidos, o joms apmokèti skirtos viešosios lèšs yra ribotos; de jure deklaruojama, kad sveikatos priežiūra Lietuvoje yra nemokama, o de facto pacientams už paslaugas, ypač stacionarias, kartais tenka mokèti neoficialiai arba savo lèšomis jie verčiami įsigyti vaistų, medicinos priemonių, apmokèti kitas su gydymu ligoninèje tiesiogiai ar netiesiogiai susijusias išlaidas; vis dažniau viešojoje erdvèje pasigirsta politikų siūlymų, kad nemokama turètų likti tik būtinoji medicinos pagalba; kad reikia įvesti priemokas už gydymą arba visiems privalomą savanoriškąji sveikatos draudimą ir kita. Teisès ị nemokamą medicinos pagalbą, kaip teisès ị sveikatos priežiūrą dalies, įtraukimas ị pripažistamų socialinių žmogaus teisių ratą kartu kelia su jos turinio apibrèžimais susijusius klausimus, kurie taip pat reikalauja išsamių mokslinių diskusijų bei išvadų teorinèje plotmèje.

2013 m. gegužès 16 d. Lietuvos Respublikos Konstituciniam Teismui (toliau Konstitucinis Teismas) paskelbus savo nutarimą byloje Nr. 47/2009-131/2010 ${ }^{8}$ buvo užpildytas konstitucinès doktrinos dèl Konstitucijos 53 straipsnio 1 dalies vakuumas. Turint omenyje, kad oficiali Konstitucinio Teismo formuluojama doktrina turi didelę ịtaką Lietuvos

2 Juškevičius, J.; Balsienè, J. Human rights in healthcare: some remarks on the limits of the right to healthcare. Jurisprudencija. 2010, 4(122): 95-110.

3 Čelkis, P. Asmens teisès ị sveikatos priežiūrą realizavimas visuomenès sveikatos priežiūros vadyboje. Sveikatos politika ir valdymas. 2010, 1(2): 63-84.

4 Birmontiene, $\mathrm{T}$. The influence of the rulings of the Constitutional Court on the development of health law in Lithuania. European Journal of Health Law. 2007, 14: 321-333; Birmontiene, T. Šiuolaikinès žmogaus teisių konstitucinès doktrinos tendencijos. Konstitucine jurisprudencija. 2007, 1(5): 202220. Birmontiené, T. Social rights in the jurisprudence of the Constitutional Court of Lithuania. Jurisprudencija. 2008, 9(111): 7-19.

5 Beliūnienè, L.; Kavoliūnaitè-Ragauskienè, E. Teisè ị sveikatos apsaugą: probleminiai sveikatos priežiūros ir sveikos aplinkos užtikrinimo aspektai. Mokslo studija. Vilnius: Teisès institutas, 2013.

${ }_{6}$ Špokiené, I. Lietuvos teisès aktuose asmeniui bei valstybei adresuotų pareigų „rūpintis sveikata“ teisinis vertinimas. Sveikatos politika ir valdymas. 2012, 1(4): 7-23; Špokienė, I. Solidarumo principo turinys ir vaidmuo sveikatos priežiūros teisinio reguliavimo srityje. Jurisprudencija. 2010, 3(121): 329-348; Špokienė, I. Retụjų vaistų prieinamumo problema ịgyvendinant teisę ị sveikatos priežiūrą. Jurisprudencija. 2008, 12(114): 64-72.

7 Markauskas, L. Konstitucinè teisè ị nemokamą gydymą: interpretavimo problemos. Jurisprudencija. 2005, 64(56): 132-139.

8 Lietuvos Respublikos Konstitucinio Teismo 2013 m. gegužès 16 d. nutarimas byloje Nr. 47/2009131/2010 [interaktyvus]. [žiūrèta 2013-06-05]. <http://www.lrkt.lt/dokumentai/2013/n130516.doc>. 
teisinei sistemai ${ }^{9}$, nekyla abejonių, kad ir šis išaiškinimas lems pokyčius teisiškai reguliuojant nemokamos medicinos pagalbos teikimą ir finansavimą. Todèl šio straipsnio tikslas - išnagrinèti ir atskleisti nemokamos medicinos pagalbos teikimo Lietuvoje konstitucinių garantijų turinị. Tyrimo objektas - teisès į nemokamą medicinos pagalbą ịtvirtinimas nacionalinèje teisèje. Uždaviniai: 1) atskleisti nemokamos medicinos pagalbos teikimo teisinius pagrindus Konstitucijoje; 2) išskirti piliečių teisès ị nemokamą medicinos pagalbą sampratos požymius, atskleidžiant jų interpretaciją konstitucinèje doktrinoje; 3) išnagrinèti piliečių ir kitų asmenų grupių teisès ị nemokamą medicinos pagalbą konstitucinių garantijų turinị. Pagrindinis metodas: sisteminès analizès.

\section{Nemokamos medicinos pagalbos teikimo garantijos Konstitucijoje}

Ilgą laiką nesant oficialaus Konstitucijos 53 straipsnio 1 dalies normų išaiškinimo, daug kas tą straipsnị skaitė skirtingai ir jo nuostatų interpretavimas pagrịstai kèlè klausimų ir neaiškumų. Pavyzdžiui, ar šio straipsnio nuostatos reiškia aiškų valstybės įsipareigojimą teikti asmenims visa apimančią nemokamą medicinos pagalbą? Ar teisẻ ị sveikatos priežiūrą ir teise ị nemokamą gydymą yra tapačios? Ar jos individualaus ar programinio pobūdžio? Ar pakankamai ir tinkamai reglamentuotas nemokamos medicinos pagalbos teikimas? Ir panašių.

Gvildendamas šio Konstitucijos straipsnio interpretavimo problemas, 2005-ais metais savo publikacijoje L. Markauskas priejo išvadą, kad ,,antrasis Konstitucijos 53 straipsnio 1 dalies sakinys paaiškina ir papildo tos pačios dalies pirmąji sakinị“. Remdamasis tuo, kad Sveikatos sistemos įstatyme yra pateikta sąvoka ,valstybès laiduojama (nemokama) asmens sveikatos priežiūra“, autorius teigia, kad , istatymų leidèjas taip iš esmės susiejo Konstitucijos 53 straipsnio 1 dalies pirmąjj ir antrąjj sakinius, o valstybès pareiga rūpintis žmonių sveikata ir laiduoti medicinos pagalbą bei paslaugas žmogui susirgus kartu reiškia ir valstybės pareigą teikti nemokamą medicinos pagalbą įstatymo nustatyta tvarka ir apimtimi ${ }^{\text {"10 }}$.

Savo nutarimu ${ }^{11}$ Konstitucinis Teismas nepaneigia aptariamos normos abiejų sakinių glaudžios sąsajos, tačiau aiškumo ị ligšiolinius teorinius svarstymus įneša komentaras, iš kurio galima spręsti, kad antruoju sakiniu įtvirtinta norma vis dèlto yra atskira piliečių konstitucinè garantija. Pabrěžiama, kad Konstitucijos 53 straipsnio 1 dalies antrojo sakinio nuostata, kad ,įstatymas nustato piliečiams nemokamos medicinos pagalbos valstybinėse gydymo ìstaigose teikimo tvarką“, yra „konstituciné piliečių teisés nemokamai ir laiku gauti kokybiškq gyvybiškai bütina medicinos pagalbq valstybinèse gydymo įstaigose garantija“. Ir kad „ši garantija nèra tapati teisei i sveikatos priežiūrą, kuri piliečiams, kaip ir kitiems asmenims,

$9 \quad$ Kartais sakoma, kad ipareigojanti, saistanti yra tik Konstitucinio Teismo nutarimo rezoliucine dalis, kurioje pripažįstama, kad tam tikras teisès aktas (jo dalis) (ne)prieštarauja Konstitucijai. Iš tiesų, formalaus ịpareigojimo paisyti Konstitucinio Teismo „samprotavimų“, motyvų bei argumentų Konstitucijoje nerasime. Tačiau reikia pripažinti, kad jie vis deltto yra tapę imperatyvu, privalomu ir ịstatymų leidejjui, ir visiems kitiems. Pirma, brandžios konstitucinès kultūros visuomenèje politikai nekvestionuoja Konstitucinio Teismo sprendimų. Antra, tiketina, kad iškilus „analogiškam“ konstituciniam ginčui Konstitucinis Teismas vadovausis jau suformuluota doktrina [Kūris, E. Konstitucija, konstitucinè doktrina ir Konstitucinio Teismo diskrecija. Baltijos ir Skandinavijos šalių konferencija „Konstitucijos aiškinimas ir tiesioginis taikymas“, Vilnius, 2002 m. kovo 15-16 d. [interaktyvus]. [žiūrèta 2013-06-10]. <http://www.lrkt.lt/PKonferencijose/12.pdf >.

10 Markauskas, L., supra note 7, p. 134.

11 Lietuvos Respublikos Konstitucinio Teismo 2013 m. gegužès 16 d. nutarimas byloje Nr. 47/2009$131 / 2010$, supra note 8 . 
užtikrinama igyvendinant Konstitucijos 53 straipsnio 1 dalyje ịtvirtintą valstybės priedermę rūpintis žmonių sveikata ir laiduoti medicinos pagalbą bei paslaugas žmogui susirgus"12.

Iš to darytina išvada, kad 53 straipsnio 1 dalies pirmasis sakinys įtvirtina prigimtinès žmogaus teisès ị kuo geresnę sveikatą garantiją ir socialinę teisę ị sveikatos priežiūrą, o antrasis yra skirtas ịtvirtinti būtent piliečių teisès ị nemokamą gydymą valstybinèse gydymo ịstaigose garantijai. Taigi teisė ị nemokamą iš valstybẻs biudžeto finansuojamą medicinos pagalbą valstybinèse gydymo įstaigose yra atskira Lietuvos piliečių konstitucinè teisè ir garantija. Žodžių ,žmogus“ ir ,pilietis“ reikšmių skirtumas pirmajame ir antrajame sakiniuose, manytina, nèra atsitiktinis. Atvirkščiai, tai konkreti Konstitucijos nuoroda, kad asmenys, kuriems taikomas šios Konstitucijos normos antrasis sakinys, skiriasi nuo asmenų, kuriems taikomas pirmasis sakinys. Vis dèlto tai anaiptol nereiškia, kad tik piliečiai turi teisę medicinos pagalbą gauti nemokamai. Nemokama medicinos pagalba taip pat sudaro valstybès ịsipareigojimo rūpintis visu asmenu sveikata ir laiduoti medicinos pagalbą bei paslaugas susirgus bet kuriam žmogui dalị. Aiškindamas 53 straipsnio 1 dalies pirmojo sakinio nuostatą, kad valstybė rūpinasi žmonių sveikata, Konstitucinis Teismas jau anksčiau yra konstatavęs, jog žmonių sveikatos apsauga yra konstituciškai svarbus tikslas, viešasis interesas, o rūpinimasis žmonių sveikata - tai valstybės funkcija ${ }^{13}$. Teismo teigimu, konstitucinę valstybės priedermę rūpintis žmonių sveikata, įskaitant ir valstybès pareigą užtikrinti medicinos pagalbą bei paslaugas žmogui susirgus, lemia nuo žmogaus orumo ir teisès i gyvybę neatsiejama prigimtinė žmogaus teisè $i$ kuo geresnę sveikata ir socialine teise i sveikatos priežiūrą. Būtent iš šių dviejų konstitucinių garantijų kyla: 1) Lietuvos piliečių teisė gauti tas sveikatos priežiūros paslaugas, kurių neapima jiems kaip piliečiams garantuota nemokama gyvybiškai būtina medicinos pagalba - t. y. sveikatos priežiūros paslaugas, apmokamas iš Privalomojo sveikatos draudimo fondo (toliau - PSDF) biudžeto; 2) kitų subjektų konstitucinė teisè tam tikra apimtimi gauti valstybès laiduojamą (nemokamą) medicinos pagalbą: visų pirma būtinąją medicinos pagalbą, o kai kurių asmenų kategorijų atžvilgiu ir kitą medicinos pagalbą bei medicinos pagalbą, apmokamą iš PSDF biudžeto.

Vadinasi, galima apibendrinti, kad tam tikra sveikatos priežiūros paslaugų dalis, o būtent piliečiams garantuota nemokama medicinos pagalba, yra ne tik valstybės priedermès rūpintis žmonių sveikata ir laiduoti medicinos pagalbą bei paslaugas žmogui susirgus dalis, bet ir atskira konstitucinė Lietuvos piliečių teisè ir garantija, kurią ịtvirtina Konstitucijos 53 straipsnio 1 dalies antrojo sakinio norma ir kurios igyvendinimo tvarka turi būti reglamentuota ịstatymu. Kitų asmenų garantijos sveikatos priežiūros srityje kildintinos iš Konstitucijos 53 straipsnio 1 dalies pirmojo sakinio normos.

\section{Piliečių teisès ị nemokamą gyvybiškai būtiną medicinos pagalbą samprata konstitucinejje doktrinoje}

Konstitucinio Teismo nutarime rašoma, kad Konstitucijos 53 straipsnio 1 dalies nuostata, kad įstatymas nustato piliečiams nemokamos medicinos pagalbos valstybinėse gydymo ìstaigose teikimo tvarką, yra „konstituciné piliečių teisés nemokamai ir laiku gauti kokybiška gyvybiškai bütinq medicinos pagalba valstybinèse gydymo įstaigose garantija. Šios konstituci-

$12 \quad$ Ibid., IV dalis, 1.4 pastraipa.

13 Lietuvos Respublikos Konstitucinio Teismo 2004 m. sausio 26 d., 2005 m. rugsėjo 29 d., 2011 m. birželio 21 d. nutarimai [interaktyvūs]. [žiūrèta 2013-06-05]. <http://www.lrkt.lt/dokumentai/2004/n040126. htm>; <http://www.lrkt.lt/dokumentai/2005/n050929>; <htm; http://www.lrkt.lt/dokumentai/2011/ n110621.htm>. 
nès piliečiu teisés igyvendinimas turi būti užtikrintas iš valstybès biudžeto lèšų"14. Šioje sampratoje galima išskirti septynis požymius, kurie igalina sistemiškai išanalizuoti ir atskleisti piliečių teisès ị nemokamą medicinos pagalbą turinio ypatumus konstitucinèje doktrinoje: 1) pilietybès; 2) pagalbos nemokamumo; 3) pagalbos svarbos; 4) pagalbos suteikimo laiku; 5) pagalbos kokybės; 6) sveikatos priežiūros ịstaigos statuso; 7) biudžetinio finansavimo.

Pilietybès požymis. Jau buvo atkreiptas dėmesys, kad 53 straipsnio 1 dalies pirmajame sakinyje yra vartojama sąvoka ,žmogus“, o antrajame - „pilietis“. Sąvoka „žmogus“ apima tiek Lietuvos Respublikos piliečius, tiek užsienio valstybių piliečius, tiek asmenis be pilietybès, t. y. kiekvieną asmenį. Sąvoka „pilietis“ apima tik Lietuvos Respublikos piliečius ir netaikoma kitų valstybių piliečiams ar asmenims be pilietybės ${ }^{15}$. Tai reiškia, jog Konstitucija tiesiogiai ịpareigoja ịstatymų leidèją piliečių nemokamos medicinos pagalbos valstybinèse gydymo įstaigose teikimo tvarką reglamentuoti ịstatymu.

Sveikatos sistemos įstatymo ${ }^{16} 49$ straipsnis nustato, kad teisę gauti valstybės laiduojamą (nemokamą) asmens sveikatos priežiūrą turi Lietuvos Respublikos, kitų valstybių piliečiai ir asmenys be pilietybės, nuolat gyvenantys Lietuvoje. Užsienio šalių piliečiams, asmenims be pilietybès, nepriskiriamiems nuolatiniams gyventojams, Lietuvos nacionalinès sveikatos sistemos ịstaigos teikia būtinąją medicinos pagalbą Sveikatos apsaugos ministerijos nustatyta tvarka, jei kitaip nenustato Lietuvos Respublikos tarptautinès sutartys.

Iš šių įstatymo nuostatų matyti, kad ne tik Lietuvos Respublikos piliečiai, bet visi nuolatiniai Lietuvos gyventojai turi teisę gauti valstybès laiduojamą (nemokamą) medicinos pagalbą - tiek būtinąją medicinos pagalbą, tiek ir kitas sveikatos priežiūros paslaugas. Tai, kad šis klausimas kitų subjektų grupių (nenuolatinių šalies gyventojų) atžvilgiu šiuo metu nèra reglamentuotas įstatymo lygmeniu, atsižvelgiant ị Konstitucijos nuorodą iš pirmo žvilgsnio nèra laikytina reglamentavimo trūkumu. Vis dèlto būtų logiška, kad nemokamos medicinos pagalbos teikimo tvarka būtų nustatyta ịstatymu visoms Lietuvos jurisdikcijoje esančių asmenų grupèms.

Medicinos pagalbos nemokamumo požymis. Sveikatos sistemos įstatymo 2 straipsnio 12 dalis apibrèžia, kad valstybès laiduojama (nemokama) asmens sveikatos priežiūra - „tai asmens sveikatos priežiūros paslaugos, apmokamos iš Privalomojo sveikatos draudimo fondo, valstybès ar savivaldybių biudžetų“. Šio ịstatymo 11 straipsnio 2 dalyje numatyta, kad Lietuvos nacionalinès sveikatos sistemos vykdomieji subjektai pagal kompetenciją teikia nemokamas ir mokamas sveikatos priežiūros paslaugas. „Nemokamos paslaugos“ (nors tiesiogiai įstatyme jos taip neịvardijamos), iš esmès yra tos asmens ir visuomenės sveikatos priežiūros paslaugos, už kurias jų gavėjai tiesiogiai nemoka sveikatos priežiūros įstaigoms, o jos apmokamos iš Privalomojo sveikatos draudimo fondo, valstybės ar savivaldybių biudžetų ar savivaldybių visuomenès sveikatos rẻmimo specialiosios programos lèšų. Sveikatos sistemos ìstatymo 47 straipsnyje pateiktas valstybès laiduojamos (nemokamos) sveikatos priežiūros sričių sąrašas. Jame, be būtinosios medicinos pagalbos ir apdraustųjų privalomuoju sveikatos draudimu sričių, taip pat nurodytos grupès asmenų, kurių sveikatos priežiūra apmokama iš valstybès biudžeto lèšų dèl jų specifinès padèties (pvz.: teismo ar teisèsaugos institucijų sulaikytų asmenų, kardomojo kalinimo vietose esančių asmenų, nuteistųjų), sergamų ligų (sergančių tuberkulioze, lytiniu keliu plintančiomis ligomis, ŽIV (AIDS), užkrečiamosiomis, endokrininèmis, psichikos, onkologinèmis ligomis; galūnių, sąnarių, kitų organų proteza-

14 Lietuvos Respublikos Konstitucinio Teismo 2013 m. gegužès 16 d. nutarimas byloje Nr. 47/2009131/2010, supra note 8 , IV dalis, 1.4 pastraipa.

15 Lietuvos Respublikos pilietybès įstatymas. Valstybès žinios. 2010, Nr. 144-7361. 2 str., 2,4,8,9 dalys.

16 Lietuvos Respublikos sveikatos sistemos ịstatymas. Valstybès žinios. 1994, Nr. 63-1231. 
vimas) ar einamų pareigų (pvz., LR karių, policijos ir kitų vidaus reikalų pareigūnų asmens sveikatos priežiūra). Matyti, kad ịstatymų leidejjas šia norma nurodo valstybės ịsipareigojimą nemokamą medicinos pagalbą organizuoti taip, kad ji būtų prieinama kiek įmanoma gausesniam subjektų ratui. Tačiau pagal finansavimo šaltinius šių paslaugų neklasifikuoja. Nèra aišku, kurios paslaugos, yra apmokamos iš privalomojo sveikatos draudimo lèšų, kurios iš valstybès biudžeto, kurios iš kitų šaltinių. Ydinga teisèkūros praktika laikytina ir tai, kad čia paslaugos tik išvardijamos, o detalesnis reglamentavimas paliekamas reglamentuoti sveikatos apsaugos ministro ịsakymuose. Tai lemia neaiškumus ir dèl teisès ị nemokamą medicinos pagalbą ịtvirtinimo, ir dèl nemokamos medicinos pagalbos apimties apibrèžimo. Dèl pastarojo aspekto aišku tik tiek, kad aptariamoje Konstitucijos nuostatoje nemokamos medicinos pagalbos apimtis yra neapibrèžta, todèl reikia pripažinti, kad interpretuoti, kad iš valstybès biudžeto lèšų turi būti besąlygiškai apmokama visa šiose ịstaigose piliečiams teikiama medicinos pagalba (juo labiau kitos sveikatos priežiūros paslaugos), anaiptol negalima. Todèl svarbu atkreipti dèmesị i šio požymio sąsajas su medicinos pagalbos svarbos/ būtinumo požymiu, taip pat turèti omenyje, kad sveikatos priežiūros paslaugos piliečiams yra garantuojamos ir remiantis valstybès priederme rūpintis žmonių sveikata (t. y. pirmuoju Konstitucijos 53 straipsnio 1 dalies sakiniu) ir gali būti finansuotos ne iš biudžeto lèšų, o iš Privalomojo sveikatos draudimo fondo ir kitų šaltinių.

Medicinos pagalbos gyvybinès svarbos požymis. Šis požymis taip pat susijęs su nemokamos medicinos pagalbos apimties aspektu. Savo nutarime Konstitucinis Teismas nekart atkreipé dèmesị ị Konstitucijos 53 straipsnio 1 dalies nuostatų sąsajas su Konstitucijos 19 straipsnio nuostata, kuria užtikrinama žmogaus gyvybės apsauga. Konstitucinis Teismas konstatuoja, kad teisè ị gyvybès išsaugojimą ir gelbejimą (ir atitinkama valstybès pareiga), kai jai kyla pavojus, ,yra neatsiejama, pamatinè prigimtinės žmogaus teisès ̨̣ kuo geresnę sveikatą dalis“. Pasak Teismo, ,,šis konstitucinių vertybių ryšys implikuoja tai, kad nemokama medicinos pagalba visiems piliečiams privalo būti užtikrinta tokia apimtimi, kokia ji yra būtina žmogaus gyvybei gelbèti ir išsaugoti“. Teigiama, kad „nustačius siauresnę šios pagalbos apimti, t. y. neužtikrinus nè minimalios, gyvybiškai svarbios nemokamos medicinos pagalbos, konstitucinė jos garantija apskritai netektų prasmės, kartu būtų pažeisti ir konstituciniai valstybès įsipareigojimai saugoti žmogaus gyvybę ir rūpintis žmonių sveikata“. Reikia pripažinti, kad ribos, kokia pagalba laikytina gyvybiškai būtina, nèra aiškios. Tačiau matyti, kad Teismas nesileidžia ị išsamesnius svarstymus aiškindamas ši aspektą. Kaip matyti, nutarime apsiribojama apibūdinimais, kad tokia pagalba turi būti „,bent minimali“, ,gyvybiškai svarbi“. Beje, matyt, tikslingai nutarime nevartojama gerai žinoma sąvoka „būtinoji medicinos pagalba“. Šiuo metu Sveikatos sistemos ịstatymo 19 straipsnio 1 dalis nurodo, kad būtinajai medicinos pagalbai priskiriama: 1) pirmoji medicinos pagalba; 2 ) instituciné (nestacionariné ar stacionarinè) skubi medicinos pagalba. Sveikatos apsaugos ministro įsakyme ${ }^{17}$ nurodoma, kad skubioji medicinos pagalba - tai tokia medicinos pagalba, kuri teikiama nedelsiant, arba neatidèliotinai, kai dèl ūmių klinikinių būklių gresia pavojus paciento ir/ar aplinkinių gyvybei arba tokios pagalbos nesuteikimas laiku sukelia sunkių komplikacijų grèsmę pacientams. Taigi iš esmès pagal dabartinị apibrèžimą būtinoji pagalba teikiama daugiausia dèl ūmių klinikinių būklių. Nors iš Konstitucinio Teismo paaiškinimo „,bent minimali“ būtų galima tokią pagalbą prilyginti būtinajai, vis dèlto teiginys, kad pagalba turètų būti užtikrinta ,,tokia apimtimi, kokia būtina žmogaus gyvybei išsaugoti, gelbèti“, galètų būti iliustruotas ir

17 Lietuvos Respublikos sveikatos apsaugos ministro $2004 \mathrm{~m}$. balandžio 8 d. ịsakymas Nr. V-208 „Dèl būtinosios medicinos pagalbos ir būtinosios medicinos pagalbos paslaugų teikimo tvarkos bei masto patvirtinimo“. Valstybès žinios. 2004, Nr. 55-1915. 
diagnozėmis, kai piliečiui teikiama pagalba turètų pranokti šiuo metu egzistuojančią teisinę būtinosios pagalbos sampratą. Grèsmė gyvybei gali būti susijusi ir su lètinèmis ligomis, pvz.; retų ligų ar būklių atveju asmens negalejimas pasinaudoti sveikatos priežiūra, veiksmingų, bet labai brangių vaistų neprieinamumas dèl lèšų trūkumo, ypač kai dẻl to kyla grèsmė asmens gyvybei, negalètų būti laikomas tinkamu šios valstybės funkcijos igyvendinimu ${ }^{18}$. Nors ministro ịsakymu šiuo metu yra nubrèžtos būtinosios pagalbos teikimo ribos ${ }^{19}$, praktikoje ne visiems gydytojams ir ne visais atvejais pavyksta jomis vadovautis. Tikètina, kad konkretumo dèl šio aspekto stoka gali įnešti sumaišties rengiat ịstatymų ir juos ịgyvendinančių teisès aktų pataisų projektus tam, kad būtų aiškiai apibrèžta nemokamos pagalbos piliečiams apimtis. Kita vertus, Konstitucinis Teismas nustato tik pagrindinius principus ir kriterijus, o konkrečių teisès nuostatų formulavimas yra įstatymų leidejo prerogatyva. İstatymų leidejui artimiausiu metu reikès aiškiai nustatyti, ne tik „gyvybiškai būtinos medicinos pagalbos“ sampratą, bet ir tai, kurios medicinos paslaugos yra būtinosios, finansuojamos iš valstybès biudžeto visiems, o kurios nèra gyvybiškai būtinos ir finansuojamos iš PSDF, kitų šaltinių.

Medicinos pagalbos teikimo laiku ir kokybès požymiai. Konstitucinis Teismas nurodo, kad ,piliečiams garantuota nemokama medicinos pagalba privalo atitikti sveikatos priežiūros paslaugoms keliamus prieinamumo ir kokybės reikalavimus, ji turi būti teikiama tokiomis sąlygomis ir tvarka, kad būtų paisoma žmogaus orumo“. Šiame Konstitucinio Teismo komentare iš esmès atsispindi Pacientų teisių ir žalos sveikatai atlyginimo įstatymo 3 straipsnio nuostatos dèl paciento teisès ị kokybiškas sveikatos priežiūros paslaugas ${ }^{20}$, taip pat Sveikatos sistemos ịstatyme numatytų būtinųjų sveikatos priežiūros prieinamumo, priimtinumo ir tinkamumo principų užtikrinimo svarbos. Tai nuoroda, kad kiekvienas pilietis turi teisę $\mathfrak{i}$ tinkamos sveikatos priežiūros standartą.

Sveikatos priežiūros įstaigos statuso požymis. Konstitucijoje nurodoma, kad nemokama medicinos pagalba piliečiams teikiama valstybinése gydymo ịstaigose. Tam, kad prisiimtus įsipareigojimus igyvendintų tinkamai, valstybei privalu užtikrinti nuolatinị reikiamo valstybinių sveikatos priežiūros įstaigų tinklo veikimą. Vis dèlto Konstitucinis Teismas nurodo, kad ,ši nuostata negali būti aiškinama kaip reiškianti, kad nemokama, iš valstybès biudžeto lèšų finansuojama, pagalba turètų būti teikiama tik valstybinèse sveikatos priežiūros įstaigose“, paaiškindamas, kad ,,siekis užtikrinti kuo geresnị nemokamos gyvybiškai bū-

18 Špokienè, I. Retųjų vaistų prieinamumo problema igyvendinant teisę ị sveikatos priežiūrą, supra note 6, p. 69.

19 Skubioji medicinos pagalba yra teikiama asmens sveikatos priežiūros i̇staigose (teikiančiose ambulatorines ir/ar stacionarines paslaugas). Pagal laiką, per kurị turi būti suteikta pagalba, atsižvelgiant $\mathfrak{i}$ asmens klinikinę būklę, skubioji medicinos pagalba skirstoma ị keturias kategorijas pagalba, kuri teikiama nedelsiant (1 kategorija), neatidèliotinai (2, 3, 4 kategorijos). Skubioji medicinos pagalba teikiama tol, kol paciento būklè tampa stabili ir tos būklès nebegalima priskirti nè vienai iš kategorijų arba pradedamas ilgalaikis paciento gyvybinių funkcijų palaikymas ir tokią būklę konstatuoja ne mažiau kaip trijų skirtingų specialybių gydytojų konsiliumas kartu su asmens sveikatos priežiūros įstaigos administracijos atstovu [Lietuvos Respublikos sveikatos apsaugos ministro $2004 \mathrm{~m}$. balandžio 8 d. ịsakymas Nr. V-208 „Dèl būtinosios medicinos pagalbos ir būtinosios medicinos pagalbos paslaugų teikimo tvarkos bei masto patvirtinimo“. Valstybės žinios. 2004, Nr. 55-1915].

20 Lietuvos Respublikos pacientų teisių ir žalos sveikatai atlyginimo įstatymo pakeitimo įstatymas. Valstybès žinios. 2009, Nr.145-6425. Kokybiškos sveikatos priežiūros paslaugos čia apibrěžtos kaip „prieinamos, saugios, veiksmingos sveikatos stiprinimo, ligų prevencijos, diagnostikos, ligonių gydymo ir slaugos paslaugos, kurias tinkamam pacientui, tinkamu laiku, tinkamoje vietoje suteikia tinkamas sveikatos priežiūros specialistas ar sveikatos priežiūros specialistų komanda pagal šiuolaikinio medicinos ir slaugos mokslo lygị ir gerą patirtị, atsižvelgdami ị paslaugos teikẻjo galimybes ir paciento poreikius bei lūkesčius, juos tenkindami ar viršydami“" $(2$ str. 8 d.). 
tinos medicinos pagalbos prieinamumą lemia ir tai, kad tais atvejais, kai tokia pagalba dèl tam tikrų aplinkybių negali būti laiku ir kokybiškai suteikta valstybinèse gydymo ịstaigose, ji gali būti teikiama ir kitose kokybiškai ir saugiai ją suteikti pajègiose sveikatos priežiūros instaigose; o jų patiriamos šios pagalbos teikimo išlaidos turi būti apmokamos iš valstybès biudžeto lèšų "Tai reiškia, kad Konstitucijoje esanti nuoroda dẻl valstybinių gydymo ịstaigų aiškintina plečiamai. Dabartinis teisinis reguliavimas nustato, kad kiekviena asmens sveikatos priežiūros ịstaiga pagal kompetenciją privalo užtikrinti (suteikti ir organizuoti) būtinąją medicinos pagalbą, t. y. jei asmuo kreipiasi ị sveikatos priežiūros ịstaigą dèl būtinosios medicinos pagalbos, gydytojas privalo pagal savo kompetenciją suteikti pacientui paslaugas, o jeigu to padaryti negali, pacientas turi būti siunčiamas gydytojo specialisto konsultacijai ar ị kitą sveikatos priežiūros įstaigą. Visos šios procedūros turi būti atliekamos nemokamai. Sprendžiant iš Konstitucinio Teismo išaiškinimo, būtinoji pagalba, kurios reikia žmogaus gyvybei gelbèti ir išsaugoti, pirmiausia turi būti suteikta ir užtikrinta valstybinèse gydymo ịstaigose. Tik jei šių ỉstaigų teikiamų paslaugų tam nepakanka, jos gali būti teikiamos ir privačiose įstaigose. Vadinasi, išimtiniais atvejais. Kažin, ar ši pozicija kvestionuoja dabartinị teisinị reguliavimą, kuriuo reikalaujama, kad kiekviena asmens sveikatos priežiūros ịstaiga pagal kompetenciją organizuotų ir suteiktų būtinąją medicinos pagalbą. Manytina, kad ne, o tik vèlgi patvirtina, kad gyvybiškai būtinos medicinos pagalbos samprata ateityje ịstatymo leidèjo turètų būti patikslinta, išplètota ir atitinkamai reglamentuota.

Biudžetinio finansavimo požymis. Konstitucinis Teismas nurodo ir nekart savo nutarimo tekste pabrèžia, kad piliečių teisès ị nemokamą gydymą ịgyvendinimas turi būti užtikrintas iš valstybès biudžeto lěšų. Visos kitos medicinos paslaugos, atsižvelgiant ị solidarumo principą ir esamus finansinius išteklius, iš PSDF. Atkreiptinas dèmesys, kad dviejų pagrindinių autonomiškų sveikatos priežiūros paslaugų finansavimo šaltinių išskyrimas yra vienas esminių šio nutarimo, komentuojant Konstitucijos 53 straipsnio 1 dalį, akcentų. Taigi dabartine situacija, kai dauguma paslaugų finansuojamos iš PSDF, tarsi prieštarauja šiai Konstitucinio Teismo išdèstytai nuostatai. Vadinasi, piliečių, arba kaip anksčiau išsiaiškinta, visų nuolatinių Lietuvos gyventojų nemokamai gyvybiškai būtinai medicinos pagalbai valstybe turètų skirti biudžetinị finansavimą iš bendrųjų valstybès asignavimų. İstatymų leidèjas turès aiškiai reglamentuoti, kokias paslaugas pilietis turi gauti už PSD lěšas, o kokias - už biudžeto finansavimą.

Teismas teisètai ribojančia nemokamos medicinos pagalbos finansavimą sąlyga pripažįsta esant valstybès ribotas galimybes: ekonominę ir socialinę padètị, visuomenès ir valstybès poreikius bei galimybes, turimus ir numatomus gauti finansinius išteklius ir valstybès ịsipareigojimus. Tačiau kartu pabrèžia, kad „taikant apribojimus negalima apskritai paneigti šios konstitucinès garantijos esmès ir valstybès priedermès rūpintis žmonių sveikata“. Teismas taip pat pažymi, kad „valstybè gali prisiimti ir didesnius finansinius įsipareigojimus, negu implikuoja konstituciné nemokamos medicinos pagalbos piliečiams garantija, tačiau, kaip minèta, tokiu atveju turi būti atsižvelgiama ị valstybès finansines galimybes - kurios nèra ir negali būti beribès - ir paisoma konstitucinių vertybių pusiausvyros, socialinès darnos, atsakingo valdymo, kitų konstitucinių imperatyvų“. Reikia sutikti, kad valstybės biudžetui negali būti užkraunama valstybès finansinių galimybių neatitinkanti našta, dèl kurios valstybẻ negalètų igyvendinti kitų savo funkcijų arba jai taptų daug sunkiau jas vykdyti. Taigi Konstitucijos 53 straipsnio nuostatų nereikètų traktuoti kaip valstybinių gydymo įstaigų absoliučios pareigos teikti išskirtinai nemokamą ir viską apimančią medicinos pagalbą. Taigi, kaip jau anksčiau yra apibendrinusi T. Birmontienè, šio Konstitucijos straipsnio interpre- 
tavimas turi būti grindžiamas kompromisu tarp asmens konstitucinès teisès ị nemokamą gydymą ir valstybės ekonominių sąlygų ${ }^{21}$.

\section{Užsieniečių ir asmenų be pilietybẻs teisẻs ị nemokamą būtinąją medicinos pagalbą konstitucinès garantijos}

Konstitucijoje nurodoma, kad žmogaus gyvybę saugo įstatymas, o valstybè rūpinasi žmonių sveikata, laiduoja pagalbą žmogui susirgus. Taigi, būtinoji pagalba yra skirta gyvybès kaip universalios vertybès, viršesnès už bet kokią pilietybę, gelbejimui. Tai patvirtina ir ankstesnè Konstitucinio Teismo doktrina, išaiškinusi, kad Konstitucijos preambuleje, II skirsnyje „Žmogus ir valstybë“, III, IV skirsnyje, kur ir įtvirtintas 53 straipsnis, taip pat ir XIII skirsnyje apibrèžtos teisès ir laisvès turi būti garantuojamos visiems Lietuvos Respublikos jurisdikcijoje esantiems asmenims $\mathrm{s}^{22} .1966 \mathrm{~m}$. priimtas Tarptautinio ekonominių, socialinių ir kultūrinių teisių pakto ${ }^{23}$, nuo 1992-ųjų galiojančio ir Lietuvoje, 12 straipsnio 1 dalies nuostatos numato, kad „valstybès, šio Pakto Šalys, pripažįsta kiekvieno žmogaus teisę turèti kuo geriausią fizinę ir psichinę sveikatą", o kaip viena iš priemonių, kurių valstybès imasi šiai teisei visiškai igyvendinti, yra sąlygų, užtikrinančių visiems medicinos paslaugas ir medicinos priežiūrą susirgus, sudarymas. Lietuvos teisinès sistemos dalis yra ir $2002 \mathrm{~m}$. ratifikuota Žmogaus teisių ir biomedicinos konvencija ${ }^{24}$, kurios 3 straipsnis skelbia, kad valstybès turi imtis priemonių, jog savo jurisdikcijoje asmenims sudarytų „lygiateisiškas galimybes gauti atitinkamos kokybès sveikatos priežiūrą“. Diskrecija dẻl konkrečių priemonių parinkimo palikta valstybėms. Pagrịsta, efektyvia ir proporcinga priemone esant tokioms aplinkybėms laikytinas laisvas ir nemokamas minimalių gydymo paslaugų prieinamumas ${ }^{25}$. Ivertinus dabartinị teisinị reguliavimą, galima tvirtinti, kad Lietuvoje prisiimti ịsipareigojimai yra igyvendinti. Sveikatos sistemos įstatymo 5 straipsnyje kaip vienas iš sveikatinimo veiklos reguliavimo principų nurodyta asmens teisių turèti kuo geresnę sveikatą lygybė, nesvarbu, kokios jis būtų lyties, rasės, tautybès, pilietybès, socialinès padèties ir profesijos. Taigi ịstatymo lygiu pripažistama ne tik Lietuvos Respublikos piliečių, bet ir užsienio valstybių piliečių ar asmenų be pilietybès teisè turèti kuo geresnę sveikatą. Sveikatos sistemos įstatymo ${ }^{26} 49$ straipsnis nustato, kad užsienio šalių piliečiams, asmenims be pilietybès, nepriskiriamiems nuolatiniams gyventojams, LNSS įstaigos teikia būtinąją medicinos pagalbą Sveikatos apsaugos ministerijos nustatyta tvarka, jei kitaip nenustato Lietuvos Respublikos tarptautinės sutartys. Taigi gyvybiškai būtina medicinos pagalba nemokamai suteikiama visiems žmonèms Lietuvoje.

${ }_{21}$ Birmontienè, T. Žmogaus teisès ir jų įtvirtinimas Lietuvos Respublikos konstitucinèje teiseje. Lietuvos konstituciné teisè. Vilnius: Lietuvos teisès universitetas, 2004, p. 337.

22 Lietuvos Respublikos Konstitucinio Teismo išvada dèl Europos žmogaus teisių ir pagrindinių laisvių apsaugos konvencijos 4, 5, 9, 14 straipsnių ir jos Ketvirtojo protokolo 2 straipsnio atitikimo Lietuvos Respublikos Konstitucijai. Valstybès žinios. 1995, Nr. 9-199.

23 Tarptautinis ekonominių, socialinių ir kultūrinių teisių paktas. Valstybés žinios. 2002, Nr. 77-3290.

24 Konvencija dèl žmogaus teisių ir orumo apsaugos biologijos ir medicinos taikymo srityje (Žmogaus teisių ir biomedicinos konvencija). Valstybès žinios. 2002, Nr. 97-4258.

25 Markauskas, L., supra note 7, p. 137.

26 Lietuvos Respublikos sveikatos sistemos ịstatymas, supra note16. 


\section{Lietuvos piliečių ir kitų asmenų teisès ị valstybės laiduojamas sveikatos priežiūros paslaugas konstitucinès garantijos}

Savo nutarime Konstitucinis Teismas nurodè, kad iš 53 straipsnio 1 dalies pirmajame sakinyje įtvirtintų žmogaus teisès ị kuo geresnę sveikatą ir socialinès teisès ị sveikatos priežiūrą kyla Lietuvos piliečių teisẻ nemokamai gauti tas sveikatos priežiūros paslaugas, kurių neapima jiems kaip piliečiams garantuota nemokama gyvybiškai būtina medicinos pagalba ir kai kurių kitų asmenų grupių konstitucinė teisė tam tikra apimtimi gauti valstybės laiduojamą (nemokamą) medicinos pagalbą. Jau cituota, kad Sveikatos sistemos įstatymo 49 straipsnis nustato, kad teisę gauti valstybės laiduojamą (nemokamą) asmens sveikatos priežiūrą turi ne tik Lietuvos Respublikos, bet ir kitų valstybių piliečiai ir asmenys be pilietybės, nuolat gyvenantys Lietuvoje. Sveikatos draudimo įstatymo ${ }^{27} 6$ straipsnis irgi numato šių asmenų galimybes patekti ị sveikatos draudimo sistemą, ịtvirtinant, kad privalomuoju sveikatos draudimu gali būti draudžiami ne tik Lietuvos piliečiai, bet ir kitų valstybių piliečiai bei asmenys be pilietybès.

Siekiant užtikrinti tokių paslaugų visiems, įskaitant socialiai jautriausias asmenų grupes, vienodą prieinamumą pagal poreikius valstybė turi sukurti tokią šių paslaugų finansavimo sistemą, kuri leistų sukaupti tokių paslaugų teikimo išlaidoms apmokèti būtinas lèšas ${ }^{28}$. Konstitucinis Teismas atkreipia demesí, kad pagal Konstituciją nereikalaujama, kad visos šios reikmès būtų finansuojamos iš valstybės biudžeto lèšų, todèl ,įstatymų leidèjas ne tik gali, bet ir privalo numatyti ir kitą visuomenès solidarumu grindžiamą būdą sukaupti reikiamas viešąsias lèšas, pavyzdžiui, pasirinkti privalomąji sveikatos draudimą“. Remiantis dabartiniu teisiniu reguliavimu teoriškai visi asmenys turi patekti ị privalomojo sveikatos draudimo sistemą. Savu ruožtu apdraustieji Lietuvoje turi teisę gauti iš PSDF biudžeto apmokamas pirminès ambulatorinès, ambulatorinès specializuotos ir stacionarinès sveikatos priežiūros paslaugas, slaugos, palaikomojo gydymo, brangių tyrimų ir procedūrų, medicininès reabilitacijos, sanatorinio gydymo bei kitas asmens sveikatos priežiūros paslaugas. Apdraustiesiems PSDF léšomis padengiamos kompensuojamųjų vaistų, medicinos pagalbos priemonių ir ortopedijos technikos priemonių ịsigijimo išlaidos ${ }^{29}$. Šiuo metu nemokamų sveikatos priežiūros paslaugų apimtis rodo ir kartu ribas nubrěžia Sveikatos sistemos ìstatymo 49 straipsnis, Sveikatos draudimo įstatymo 10 straipsnio 5 dalis, Mokamų asmens sveikatos priežiūros paslaugų teikimo ir apmokejjimo tvarka ${ }^{30}$, nemaža gausa kitų Sveikatos apsaugos ministro įsakymų. Vis dèlto po šio Konstitucinio Teismo nutarimo įstatymų leidèjui teks aiškiau atskirti iš valstybès biudžeto ir iš PSDF kompensuojamas paslaugas (aiškiai apibrèžti šio draudimo lèšomis finansuojamų asmens sveikatos priežiūros paslaugų apimtị), nes kol kas aiškesnių tokio paslaugų ir jų finansavimo atskyrimo nẻra. Konstitucinio Teismo teigimu, tai gali būti padaryta nurodant paslaugas, teikiamas apdraustiesiems už šio draudimo lèšas, arba, priešingai, tas, kurių teikimo išlaidos iš draudimo lèšų nèra apmokamos ir už

Lietuvos Respublikos sveikatos draudimo ịstatymas. Valstybės žinios. 1996, Nr. 55-1287.

28 Lietuvos Respublikos Konstitucinio Teismo 2013 m. gegužès 16 d. nutarimas byloje Nr. 47/2009$131 / 2010$, supra note 8.

29 Gydyma užtikrina privalomojo sveikatos draudimo léšos. Valstybinès ligonių kasos prie Lietuvos Respublikos sveikatos apsaugos ministerijos pranešimas [interaktyvus]. [žiūrèta 2013-06-11]. <http:// www.vlk.lt/vlk/pr/?page =item\&kat_id=1\&date=2009-08-14\&item_id=1721>.

30 Lietuvos Respublikos sveikatos apsaugos ministro 1999 m. liepos 30 d. įsakymas Nr. 357 „Dèl Mokamų asmens sveikatos priežiūros paslaugų sąrašo, kainų nustatymo ir jų indeksavimo tvarkos bei šių paslaugų teikimo ir apmokejjimo tvarkos“. Valstybés žinios. 1999, Nr. 67-2175. 
kurias turi būti sumokama iš privačiu šaltinių, o jeigu tiksliai nurodyti neịmanoma, turi būti nustatyti pakankamai aiškūs kriterijai, pagal kuriuos būtų galima spręsti konkrečiu atveju. Teismas atkreipia dėmesĭ, kad iš PSDF apmokamos tik tos apdraustų asmenų sveikatos priežiūros paslaugos, kurių neapima nemokama medicinos pagalba ir kad tokia pagalba turi būti prieinama tik tiems žmonèms, kurie moka šias įmokas arba už juos tai daro valstybè, taip pabrèždamas privalomojo sveikatos draudimo visuotinumą.

Plètodamas solidarumo principo turinį Teismas nurodo, kad ,valstybès pareiga sukurti visuomenès solidarumu pagrịstą sveikatos priežiūros finansavimo viešosiomis lèšomis sistemą, kuri leistų užtikrinti pakankamą sveikatos priežiūros prieinamumą, negali būti aiškinama taip, esą visuomenè turi prisiimti visų įmanomu asmens sveikatos priežiūros paslaugų finansavimo naštą ${ }^{\text {“31. }}$. Siekdamas užtikrinti sveikatos priežiūros prieinamumą visiems neatsižvelgiant $\mathfrak{i}$ asmens pajamas, ịstatymų leidẻjas gali tam tikrų socialiai jautriausių asmenų grupių privalomojo sveikatos draudimo naštą perkelti valstybei, tačiau tai turi būti daroma atsakingai, neiškreipiant visuomenès solidarumo esmès, nepaneigiant asmens paskatų rūpintis savo sveikata ir pareigos pagal išgales prisidèti prie jos priežiūros finansavimo, - taigi taip, kad nebūtų pažeista socialinė darna, asmens ir visuomenés interesų bei atsakomybės pusiausvyra. Konstitucinis Teismas ne kartą yra konstatavęs, kad pilietinėje visuomeneje solidarumo principas nepaneigia asmeninès atsakomybès už savo likimą; pripažinti abipusę asmens ir visuomenès atsakomybę yra svarbu užtikrinant socialinę darną, laiduojant asmens laisvę ir galimybę apsisaugoti nuo sunkumų, kurių žmogus vienas nepajègtų įveikti (Konstitucinio Teismo 1997 m. kovo 12 d., 2007 m. rugséjo 26 d. nutarimai, $2010 \mathrm{~m}$. balandžio 20 d. sprendimas, $2012 \mathrm{~m}$. vasario 6 d., $2012 \mathrm{~m}$. vasario $27 \mathrm{~d}$. nutarimai). Asmens sveikatos priežiūros finansavimo teisiniu reguliavimu turètų būti sudarytos paskatos kiekvienam asmeniui rūpintis savo sveikata, prisiimti pareigą pagal išgales prisidèti prie jos priežiūros finansavimo, atsakingai ir racionaliai naudotis sveikatos priežiūros paslaugomis. Taigi pagal Konstituciją įstatymų leidejas turi igaliojimus nustatyti ir tai, kad už tam tikras sveikatos priežiūros paslaugas turi būti atsiskaitoma iš privačių finansavimo šaltinių, kaip antai iš Savanoriškojo sveikatos draudimo fondų lěšų, tiesioginiais pačių asmenų mokèjimais ir kt. Taigi, skirtingai nei gyvybiškai būtinosios medicinos pagalbos teikimo atveju, dèl privataus sektoriaus dalyvavimo teikiant sveikatos priežiūros paslaugas, finansuojamas iš PSDF, esminių prieštaravimų Konstitucinis Teismas nę̧žvelgè.

Apibendrinant matyti, kad nagrinejjamu aspektu pateiktos Konstitucinio Teismo argumentacijos pagrindinis akcentas - aiški skirtis tarp gyvybiškai būtinos medicinos pagalbos, kuri finansuojama iš valstybės biudžeto visiems, nepriklausomai nuo socialinio draudimo i̇mokų, bei „kitų sveikatos priežiūros paslaugų“, kurių valstybẻ nepajègia padengti ir kurios turi būti finansuojamos iš PSD ar kitų šaltinių. Teismas pabrěže valstybės pareigą sukurti visuomenès solidarumu pagrịstą sveikatos priežiūros finansavimo viešosiomis lèšomis sistemą, kuri leistų užtikrinti pakankamą sveikatos priežiūros prieinamumą. Kita vertus, taip pat pabrèžta, kad pakankamas prieinamumas anaiptol nereiškia, kad visuomene turi prisiimti visų įmanomų paslaugų finansavimą, nes tokie ịsipareigojimai visų pirma priklauso nuo esamų išteklių, ir kad pilietineje visuomeneje solidarumo principo egzistavimas neatmeta paties asmens atsakomybès už savo sveikatą. Iš tiesų, valstybès indèlį siekiant užtikrinti asmenų garantijas sveikatos priežiūros srityje riboja ne tik valstybės turimi ištekliai - finansiniai, žmo-

31 Lietuvos Respublikos Konstitucinio Teismo 2013 m. gegužès 16 d. nutarimas byloje Nr. 47/2009$131 / 2010$, supra note 8 . 
giškieji, medicininių priemonių (prietaisų, vaistų), sveikatos priežiūros ịstaigų skaičiaus ir jų teikiamų paslaugų apimčių ribotumas, bet ir nacionaliniai sveikatos priežiūros prioritetai ${ }^{32}$.

Tyrimų duomenimis, teisès ị sveikatos priežiūros užtikrinimą Lietuvos gyventojai pastaraisiais metais vertina labiau neigiamai nei teigiamai. 2008-2011 m. atliktų gyventojų apklausų duomenimis, daugelis respondentų: atitinkamai 2009, 2010 ir 2011 m. - 60,0, 60,9 ir 68,4 proc. mano, kad konstitucinè teisè i̇ sveikatos priežiūrą Lietuvoje užtikrinta tik iš dalies, kad neužtikrinta - atitinkamai 12,3, 13,5 ir 11,6 proc., kad visiškai užtikrinta - atitinkamai $22,3,16,9$ ir 7,8 proc. ${ }^{33}$ Šie duomenys perša išvadą, kad ịstatymų leidèjas turi peržiūrèti nemokamos medicinos pagalbos teikimo teisinị reguliavimą, kad valstybė galètų aktyviau imtis priemonių sukurti sąlygas, palankias pasiekti ir išlaikyti aukščiausią galimą žmonių sveikatos lygi (taip pat ir kad patys asmenys labiau rūpintųsi savo sveikata), siekti, kad nuolat gerètų socialinès bei ekonominès sąlygos, kurios lemia šios teisès igyvendinimą.

\section{Išvados ir pasiūlymai}

1. Teisè ị nemokamą medicinos pagalbą apima dvi Konstitucijos garantuojamas teises: teisę i gyvybiškai būtiną medicinos pagalbą ir teisę i kitas sveikatos priežiūros paslaugas. Pirmąją implikuoja Lietuvos piliečių teisès ị nemokamą gydymą valstybinèse gydymo įstaigose garantija (LRK 53 str. 1 d. antras sakinys) bei kiekvieno žmogaus teisè i gyvybę (LRK 19 str.) ir kuo geresnę sveikatą (LRK 53 str. 1 d. pirmas sakinys), antrąją - socialinè teisè i sveikatos priežiūrą (LRK 53 str. $1 \mathrm{~d}$. pirmas sakinys).

2. Teisès ị nemokamą medicinos pagalbą turinio ypatumai konstitucinèje doktrinoje atskleidžiami per 1) pilietybès; 2) pagalbos nemokamumo; 3) pagalbos gyvybinès svarbos; 4) pagalbos teikimo laiku; 5) pagalbos kokybès; 6) sveikatos priežiūros ịstaigos valstybinio statuso; 7) biudžetinio finansavimo požymius. Konstitucinis Teismas patvirtino tai, kad gyvybiškai būtina (bent minimali) medicinos pagalba turi būti laiku ir kokybiškai teikiama visiems Lietuvos Respublikos jurisdikcijoje esantiems asmenims, nepriklausomai nuo socialinio draudimo įmokų ir finansuojama iš valstybès biudžeto. Jo lèšomis apmokamas gyvybiškai būtinas medicinos pagalbos paslaugas gali teikti ir privačios įstaigos, tačiau tik išimtiniais atvejais.

3. Privalomasis sveikatos draudimas konstitucineje doktrinoje vertinamas kaip būtina visuomenès solidarumu pagrịsta sveikatos priežiūros finansavimo viešosiomis lèšomis sistema, leidžianti užtikrinti pakankamą sveikatos priežiūros prieinamumą. İstatymų leidejjui reikia aiškiai apibrěžti gyvybiškai būtinos medicinos pagalbos teikimo ribas ir nurodyti medicinos pagalbos paslaugas, kurios nèra gyvybiškai būtinos ir turi būti finansuojamos iš PSDF. Taip pat būtina aiškiai nurodyti, kokias sveikatos priežiūros paslaugas asmenys galès gauti tik tada, jei kaups lěšas savanoriškame (Lietuvoje iki šiol neegzistuojančiame) sveikatos draudimo fonde ar už jas sveikatos priežiūros ịstaigai susimokès iš savo asmeninių lèšų. Konstitucinis Teismas patvirtino, kad nemokamos sveikatos priežiūros paslaugų teikimo apimtis visų pirma priklauso nuo esamų išteklių, o pilietinèje visuomenèje solidarumas neatmeta asmens atsakomybės už savo sveikatą.

32 Beliūnienè, L.; Kavoliūnaitè-Ragauskienè, E., supra note 5, p. 11.

33 Lietuvos gyventoju nuomone apie privalomojo sveikatos draudimo sistema, ligoniu kasu ir sveikatos priežiūros ịstaigų veikla 2009, 2010, $2011 \mathrm{~m}$. Valstybinè ligonių kasa prie Lietuvos Respublikos sveikatos apsaugos ministerijos [interaktyvus]. [žiūrèta 2013-05-27]. <http://www.vlk.lt/resources/files/2012/ot her/20120327TyrimoPristatymasSAM.pdf> . 
4. Kiekvieną sveikatos priežiūros paslaugų teikimo ir apmokejjimo tvarką privalu reglamentuoti įstatymo lygiu, nepaneigiant prigimtinés žmonių teisés ị gyvybę ir gerą sveikatą.

\section{Literatūra}

1. Beliūnienè, L.; Kavoliūnaitè-Ragauskienè, E. Teisé $i$ sveikatos apsauga: probleminiai sveikatos priežiūros ir sveikos aplinkos užtikrinimo aspektai. Mokslo studija. Vilnius: Teisès institutas, 2013.

2. Birmontienè, T. Šiuolaikinès žmogaus teisių konstitucinès doktrinos tendencijos. Konstitucine jurisprudencija. 2007, 1(5): 202-220.

3. Birmontienè, T. Žmogaus teisès ir jų ịtvirtinimas Lietuvos Respublikos konstitucinèje teisèje. Lietuvos konstituciné teisè. Vilnius: Lietuvos teisès universitetas, 2004.

4. Birmontiené, T. The influence of the rulings of the Constitutional Court on the development of health law in Lithuania. European Journal of Health Law. 2007, 14: 321333.

5. Birmontiene, T. Social rights in the jurisprudence of the Constitutional Court of Lithuania. Jurisprudencija. 2008, 9(111): 7-19.

6. Čelkis, P. Asmens teisès ị sveikatos priežiūrą realizavimas visuomenès sveikatos priežiūros vadyboje. Sveikatos politika ir valdymas. 2010, 1(2): 63-84.

7. Gydyma užtikrina privalomojo sveikatos draudimo léšos. Valstybinès ligonių kasos prie Lietuvos Respublikos sveikatos apsaugos ministerijos pranešimas [interaktyvus]. [žiūrèta 2013-06-11]. <http://www.vlk.lt/vlk/pr/?page =item\&kat_id=1\&date=2009-08-14\&item _ $\mathrm{id}=1721>$.

8. Juškevičius, J.; Balsienė, J. Human rights in healthcare: some remarks on the limits of the right to healthcare. Jurisprudencija. 2010, 4(122): 95-110.

9. Konvencija dèl žmogaus teisių ir orumo apsaugos biologijos ir medicinos taikymo srityje (Žmogaus teisių ir biomedicinos konvencija). Valstybės žinios. 2002, Nr. 97-4258.

10. Kūris, E. Konstitucija, konstitucinè doktrina ir Konstitucinio Teismo diskrecija. Baltijos ir Skandinavijos šalių konferencija „Konstitucijos aiškinimas ir tiesioginis taikymas“ [interaktyvus] Vilnius, 2002 m. kovo 15-16 d. [žiūrèta 2013-06-10]. <http://www.lrkt.lt/ PKonferencijose/12.pdf $>$.

11. Lietuvos Respublikos Konstitucija. Valstybės žinios. 1992, Nr. 33-1014.

12. Lietuvos Respublikos pacientų teisių ir žalos sveikatai atlyginimo ịstatymo pakeitimo istatymas. Valstybès žinios. 2009, Nr. 145-6425.

13. Lietuvos Respublikos pilietybės įstatymas. Valstybės žinios. 2010, Nr. 144-7361.

14. Lietuvos Respublikos sveikatos draudimo įstatymas. Valstybés žinios. 1996, Nr. 55-1287.

15. Lietuvos Respublikos sveikatos sistemos ịstatymas. Valstybés žinios. 1994, Nr. 63-1231.

16. Lietuvos Respublikos Konstitucinio Teismo 2013 m. gegužès 16 d. nutarimas byloje Nr. 47/2009-131/2010 [interaktyvus]. [žiūrèta 2013-06-05]. http://www.lrkt.lt/ dokumentai/2013/n130516.doc >.

17. Lietuvos Respublikos Konstitucinio Teismo 2004 m. sausio 26 d., 2005 m. rugsejjo 29 d., $2011 \mathrm{~m}$. birželio $21 \mathrm{~d}$. nutarimai [interaktyvūs]. [žiūrèta 2013-06-05]. <http://www.lrkt. lt/dokumentai/2004/n040126.htm>; <http://www.lrkt.lt/dokumentai/2005/n050929>; <htm; http://www.lrkt.lt/dokumentai/2011/n110621.htm>. 
18. Lietuvos Respublikos Konstitucinio Teismo išvada dèl Europos žmogaus teisių ir pagrindinių laisvių apsaugos konvencijos 4, 5, 9, 14 straipsnių ir jos Ketvirtojo protokolo 2 straipsnio atitikimo Lietuvos Respublikos Konstitucijai. Valstybės žinios. 1995, Nr. 9-199.

19. Lietuvos Respublikos sveikatos apsaugos ministro $1999 \mathrm{~m}$. liepos $30 \mathrm{~d}$. įsakymas Nr. 357 „Dèl Mokamų asmens sveikatos priežiūros paslaugų sąrašo, kainų nustatymo ir jų indeksavimo tvarkos bei šių paslaugų teikimo ir apmokẻjimo tvarkos“. Valstybès žinios. 1999, Nr. 67-2175.

20. Lietuvos Respublikos sveikatos apsaugos ministro $2004 \mathrm{~m}$. balandžio $8 \mathrm{~d}$. ịsakymas Nr. V-208 „Dèl būtinosios medicinos pagalbos ir būtinosios medicinos pagalbos paslaugu teikimo tvarkos bei masto patvirtinimo“. Valstybès žinios. 2004, Nr. 55-1915.

21. Lietuvos gyventojų nuomone apie privalomojo sveikatos draudimo sistema, ligoniu kasu ir sveikatos priežiūros ịstaigu veikla 2009, 2010, $2011 \mathrm{~m}$. Valstybinè ligonių kasa prie Lietuvos Respublikos sveikatos apsaugos ministerijos [interaktyvus]. [žiūrèta 2013-0527]. <http://www.vlk.lt/resources/files/2012/other/20120327TyrimoPristatymasSAM. pdf $>$.

22. Markauskas, L. Konstitucinė teise ì nemokamą gydymą: interpretavimo problemos. Jurisprudencija. 2005, 64(56): 132-139.

23. Špokienè, I. Lietuvos teisès aktuose asmeniui bei valstybei adresuotų pareigų „rūpintis sveikata" teisinis vertinimas. Sveikatos politika ir valdymas. 2012, 1(4): 7-23.

24. Špokienė, I. Retųjų vaistų prieinamumo problema igyvendinant teisę ì sveikatos priežiūrą. Jurisprudencija. 2008, 12(114): 64-72.

25. Špokienè, I. Solidarumo principo turinys ir vaidmuo sveikatos priežiūros teisinio reguliavimo srityje. Jurisprudencija. 2010, 3(121): 329-348.

26. Tarptautinis ekonominių, socialinių ir kultūrinių teisių paktas. Valstybès žinios. 2002, Nr. 77-3290.

\title{
The Constitutional Guarantees of Providing Free Medical Aid
}

\author{
Indrẻ Špokienė \\ Mykolas Romeris University, Lithuania
}

\section{Summary}

The theoretical and practical issues of free medical aid are currently very relevant, considering the increasing need for health care services and limited resources. This paper analyzes the nature of constitutional guarantees of providing free legal aid in Lithuania and the content and peculiarities of these guarantees in the current constitutional doctrine. The ruling of the Constitutional Court of 16 May, 2013 is a very important source in this regard, because it explains the norm of Article 53 part 1 of the Constitution of the Republic of Lithuania.

The paper established that the right to free medical aid includes these rights guaranteed by the Constitution: the right to the medical aid necessary for life and the right to other health care services. These rights are closely interconnected with every individual's human right to have good health, right to life and human dignity. It has been clarified that the constitutional doctrine reveals the concept of the right to free medical aid through these seven features: 1 . Nationality; 2. The aid is free of charge; 3 . The aid's significance for life; 4 . The aid's timeliness; 5. The aid's quality; 6 . The state's status of the health care institution; 7 . The budget financing. The Constitutional Court has confirmed that the medical aid that is necessary for life (at least 
the minimal aid) must be provided in a timely manner, it must be of good quality, provided to all persons within the jurisdiction of the Republic of Lithuania and funded from the state's budget. The new position is that the services of necessary aid, which are funded by the state's budget funds, can be provided by private health care institutions only in exceptional situations. These aspects will have to be implemented by the relevant legislation of the Republic of Lithuanian in the near future.

Analysis of the constitutional guarantees of Lithuanian nationals and other persons on receiving health care services, which are not considered as necessary medical aid, showed that compulsory health insurance in the constitutional doctrine is seen as the necessary system of funding health care services by public funds. The system is based on societal solidarity and allows ensuring sufficient accessibility of health care services. The current legal regulation lacks clarity, therefore, the paper offers setting clear limits of providing medical aid and, specifically, establishing the medical aid services that are not necessary for life and must be funded from the compulsory health insurance fund. It is also suggested to stipulate clearly, which health care services persons can receive, provided that they save the funds in voluntary health care fund (which practically does not function in Lithuania to this date), or otherwise they pay from their own funds to the health care institution. Each procedure for providing and paying for health care services must be regulated at the statutory level, considering the fundamental human right to life and good health.

Keywords: free of charge treatment, right to state guaranteed medical aid, right to free of charge treatment, health care, right to health care, essential medical aid.

Indrè Špokienė, Mykolo Romerio universiteto Teisès fakulteto Teisès filosofijos ir istorijos katedros docentė. Mokslinių tyrimų kryptys: sveikatos teisès teorinės ir praktinès problemos, biomedicinos ir biotechnologijų pasiekimų ịtaka žmogaus teisių apsaugai.

Indrẻ Špokienė, Mykolas Romeris University, Faculty of Law, Department of Philosophy of Law and Legal History, Associate Professor. Research interests: theoretical and practical problems of health law, the impact of biomedicine and biotechnology development on human rights. 